\title{
ÇOCUĞUN ÖZEL YAŞAMINA SAYGI HAKKININ AVRUPA İNSAN HAKLARI SÖZLEŞMESİ KAPSAMINDA DEĞERLENDİRILMESI
}

\author{
Fatmagül KALE ÖZÇELİK*
}

\section{$\ddot{O} Z$}

Özel yaşama saygl hakkl, Avrupa İnsan Hakları Sözleşmesi'nin 8. maddesinde düzenlenen ve koruma alanı Avrupa Insan Hakları Mahkemesi'nin kararlarlyla genişletilmiş önemli medeni haklardan birisidir. Ilgili hak, sadece devletlerin bireylerin kendi kişisel alanlarına müdahale etmeme ve saygl gösterme eylemlerini gerektirmez; ayrıca devletin kişilerin dış dünyayla bağlantılarına ilişkin pozitif edimlerde bulunma yükümlülüğünü doğurur. Söz konusu genel kurallar herkes gibi çocuğun özel yaşamına saygı hakkı bakımından da geçerlidir. Ancak haktan yararlanan, dezavantajll gruplardan birisi olarak kabul edilen çocuklar olduğu için devletlerin hakkın korunmasinda daha özenli olmaları gerekir. Nitekim mahremiyet algısl, rıza gösterme yetisi gibi özellikleri henüz gelişmemiş çocukların özel yaşamları başta kamu görevlileri olmak üzere, aileler ve üçüncü kişiler tarafindan da kolaylıkla suiistimal edilebilir. Bu nedenle sözleşme tarafi devletlerin yetişkinlere nazaran çocuğun özel yaşamına saygı hakkına ilişkin daha sık koruma öngörmeleri gerekir. Çalışmamızda da, Avrupa İnsan Hakları Sözleşmesi sisteminde çocuğun özel yaşamına saygı hakkının Avrupa Insan Hakları Mahkemesi tarafindan devletlere, ailelere ve üçüncü kişilere karşı doğurduğu yükümlülüklerin ortaya konulması amaçlanmaktadır.

Anahtar Kelimeler: Çocuk, özel yaşama saygl hakkl, "shareting/ paylaşananababalık", AIHM, insan haklart.

\section{EVALUATION OF THE CHILD'S RIGHT TO RESPECT FOR PRIVATE LIFE UNDER THE EUROPEAN CONVENTION ON HUMAN RIGHTS}

\section{ABSTRACT}

The right to respect for private life is one of the important civil rights enshrined in Article 8 of the European Convention on Human Rights and extended by the decisions of the European Court of Human Rights. The right does not only require the act of the state not to interfere and respect individuals personal spheres; it also entails the obligation of the state to make positive actions regarding the contacts of individuals Dr. Öğr. Üyesi, Ondokuz Mayıs Üniversitesi Hukuk Fakültesi Genel Kamu Hukuku
Anabilim Dalı, e-posta: fatmagul.kale@omu.edu.tr

ORCID ID: 0000-0002-8700-2150

DOI : 10.34246/ahbvuhfd.733281

Yayın Kuruluna Ulaştı̆̆ı Tarih $: 19 / 12 / 2019$

Yayınlanmasının Uygun Görüldüğü Tarih: 05/03/2020 
with the outside world. These general rules also apply to the child's right to respect for the private life. However, since children are one of the disadvantaged groups that enjoy the right, states need to be more careful in protecting the right. As a matter of fact, the private lives of children whose features such as perception of privacy and ability to show consent have not developed yet can easily be abused by public officals, families and third parties. Therefore, the contracting states should provide for more strict protection of the child's right to respect for private life than adults. In this study aims to reveal the obligations of the right to respect for private life of child to states, families and third parties.

Keywords: Child, the right to respect for private life, shareting, ECtHR, human rights.

\section{Giriş}

Çocukların özel yaşama saygı hakkı tıpkı yetişkinlerin özel yaşama saygı hakkı gibi korunur. Nitekim özel yaşama saygı hakkını düzenleyen insan hakları sözleşmelerinin de belirttiği gibi "herkes" bu hakka sahiptir. Bu nedenle her iki özne türünde de, bireylerin özel yaşam hakkının nasıl sınırlandırılacağı, hangi bilgilerinin özel olarak kabul edilebileceği ve hangi ilişkilerinin gizli olarak kabul edilmesi gerektiği önemlidir. Burada esasen çocuk ya da yetişkin şeklinde herhangi bir ayrıma gitmeden yetişkinlerin özel yaşama saygı haklarına ilişkin soru ve cevapların çocukların özel yaşama saygı haklarına da uygulanması gerektiği sonucuna varılır. Bu genel geçer kural insan hakları hukukunun genel teorisi çerçevesinde eşyanın tabiatı gereği ortaya çıkar. Ancak çocuklar nezdinde özel yaşama saygı hakkının korunmasına ilişkin sorularla dolu alanlar bulunur. Özellikle yaşadığımız çağın teknoloji ve internet çağı olduğu göz önünde bulundurulduğunda bu hak çocuklar nezdinde daha da önemli hale gelir. Çocuklarının özel yaşamlarını sosyal medya aracılığıyla kamuda herkese görünür kılan ailelerin yaygınlaşması ve doktrinde artık bu durumun "shareting" olarak adlandırılmasıyla beraber çocuğun özel yaşamına sayg1

1 "Shareting" kelimesi, İngilizce karşı1lığ “paylaşmak" anlamına gelen "share" ve ebeveynlik yapma anlamına gelen "parenting" sözcüklerinin birleşimidir. Kelimenin Türkçe karşıllğ 1 henüz tam olarak bulunmasa da, literatürde "paylaşan anababalık" şeklinde kavramlara rastlanmaktadır. Kelime, ebeveynlerin fotoğraflarını paylaşma eylemleri olarak ilk olarak 2012 y1lında Wall Street Gazetesi yazar1 Steven Leckart tarafindan "over-sharenting" olarak kullanılmıştır. Kelimenin sözlük tarafından tanımlanması ise ilk kez 2015 yılında Collins adlı sözlük tarafından gerçekleşmiştir. Sözlüğe göre "sharenting" kavramı, çocukları hakkında sosyal medya hesaplarından düzenli ve detaylı olarak paylaşım yapan anne baba pratiği" olarak tanımlanmıştır. ERİŞİR/ERİŞiR, s. 53. Stacey B. Steinberg'de "sharenting" konusuna odaklanan çalışmasında bu kavramı, ebeveynlerin çocuklarının yaşamlarılyla ilgili ayrıntıların internet aracılığıyla paylaşılma şekli olarak tanımlamıştır. STEINBERG, s. 842. 
hakkının nerede ve kimler nezdinde başladığı soruları çoğalmış ve cevapları aranmaya başlamıştır. İşte çocuğun özel yaşamının kendi ailesi eliyle dahi kamusal alana taşınmasıyla beraber çocuğun özel yaşama saygı hakkının bir yetişkinin özel yaşama saygı hakkından farklı olarak ele alınması ihtiyacı doğmuştur.

Esasen çocuk ile yetişkinin özel yaşama saygı haklarının ayrı olarak değerlendirilmesi yaşa bağlı olarak ele alınması gereken sosyal bir zorunluluktur. Nitekim mahremiyet gereksinimi ve mahremiyeti kullanma yetkisi yaşa bağlı olarak ortaya çıkan bir durumdur². Kuşkusuz bir bebeğin mahremiyete olan ihtiyacı bir yetişkininkiyle ya da bir çocuğun mahremiyete ilişkin irade yetisiyle -ki genellikle farkında olmayacaktır- yetişkinin mahremiyetine ilişkin iradesini kullanma özerkliği aynı olmayacaktır. Hatta çocukların gelişimlerinin farklı aşamalarında dahi farklı mahremiyet ihtiyaçlarının olduğu kabul edilmelidir. Dolayısıyla bebekler ve çocuklar mahremiyetlerine ilişkin herhangi bir saldırıda yetişkinlere oranla daha etkisiz ve dolayısıyla savunmasızdırlar. Bu durum, çocukların Avrupa İnsan Hakları Sözleşmesi’nin 8. maddesiyle korunan farklı çıkarlara sahip oldukları ve kendileri için sınır koyabilme yetisine sahip olamadıklarından ötürü daha sıkı bir korumaya ihtiyaç duyabilecekleri anlamına gelir. Bu kapsamda çalışmada öncelikli amaç, Avrupa İnsan Hakları Mahkemesi'nin kararlarında özel yaşama saygı hakkı kapsamında çocukların farklı ihtiyaçlarını göz önünde bulundurup bulundurmadığının ortaya çıkarılmasıdır. Sonrasında ise çocuğun özel yaşama saygı hakkının korunmasında ailelerin " $r ı z a$ " faktörünü araştırmaktır. Bahsedilen amaçlara ulaşmak için çalışmada öncelikle genel olarak özel yaşama saygı hakkı hakkında genel bir bilgi verilecektir. Devamında ise çocuğun özel yaşama saygı hakkına ilişkin Avrupa İnsan Hakları Mahkemesi kararları değerlendirilecektir. Çalışmanın kapsamı açısından belirtmek gerekir ki, 8. madde özel yaşama saygı hakkı dışında aile yaşamına, konuta ve haberleşmeye saygı hakkını da düzenler. Ancak çalışmanın sınırlandırılması amacıyla, bahsi geçen bu haklar kapsam dişında tutularak, çocuğun yalnızca özel yaşamına saygı hakkı ele alınacaktır.

\section{II. Özel Yaşama Saygı Hakkı ve Mahremiyet Hakkına İlişsin Kavramsal Analiz}

Avrupa İnsan Hakları Sözleşmesi'nin 8. maddesini kaleme alan çalışmaların, maddede düzenlenen hakka karş11ık olarak "özel yaşama saygı

Diğer bir tanıma göre ise ilgili kavram, bir çocuğa ilişkin haber, görüntü vb. durumlarını paylaşmak için sosyal medyanın alışılmış biçimde kullanılmasıdır. BESSANT, s. 7.

2 HUGHES, s. 457. 
hakkl" kavramının yanı sıra "mahremiyet hakkl" terimini de kullanmış oldukları gözlenir. $\mathrm{Bu}$ anlayışın uzantısı olarak çocuğun 8 . maddede düzenlenen haklarını konu edinen çalışmalar yaygın bir şekilde mahremiyet hakk1 kavramını kullanmaktadır. Uluslararası doktrinde de William A. Schabas tarafindan Evrensel İnsan Hakları Bildirisi'nin 12. maddesinde ve Medeni ve Siyasi Haklar Sözleşmesi'nin 17. maddesinde kullanılan "privacy" yani mahremiyet kavramının Avrupa İnsan Hakları Sözleşmesi'nde yer alan özel yaşam kavramıyla aynı anlama geldiği ileri sürülmüştür. Yazara göre, her iki kavramında hukuki sonuçları aynıdır ve Avrupa İnsan Hakları Sözleşmesi'nde bu kavramın kullanılması Sözleşme'nin orijinal dili olan Fransızcadan kaynaklanmaktadır. Ona göre, Fransızca taslağında kullanılan "vie privee" kavramının karşıllğı olarak Sözleşme'de "private life" kavramı kullanılmıştır.

Ancak bu görüşe katılmak mümkün değildir. Çünkü Avrupa İnsan Hakları Sözleşmesi sisteminde 8. maddeye özgülenmiş herhangi bir çalışmanın mahremiyet hakkı kavramını kullanılması yerinde değildir. Öyle ki bu sistemde her iki kavram birbirlerinden farklıdır. Mahremiyet hakkının İngilizce karşılığ İngilizce karşıllı̆̆ "right to respect for private life"dır. Avrupa İnsan Hakları Sözleşmesi'nin orijinal dili olan İngilizce halinde de 8. madde açıkça "right to respect for private and family life" şeklinde düzenlenmiştir. Örneğin bölgesel alanda geçerli olan Afrika Çocuk Hakları ve Esenliği Şartı'nın 10. maddesi "protection of privacy" yani "mahremiyetin korunması" başlığını taşır. Dolayısıyla Afrika Çocuk Hakları ve Esenliği Şartı'nı konu edinen bir çalışmada mahremiyet hakkı kavramı kullanılabilir. Ancak Avrupa İnsan Hakları Sözleşmesi özelinde özel yaşama saygı hakkı kavramının kullanılması gerekir. Kaldı ki, çalışmamız amacıyla madde 8 özelinde yapılan karar taramalarında, Avrupa İnsan Hakları Mahkemesi'nin mahremiyet hakk1 şeklinde bir kavramına henüz rastlanmamıştır. Bu durumun yanı sıra özel yaşama saygı hakkı ile mahremiyet hakkı aynı anlama gelecek şekilde kullanılamaz. Nitekim çalışmanın devamında da belirtileceği üzere, özel yaşama saygı hakkının konusu mahremiyet hakkından çok daha geniştir. Örneğin Avrupa Konseyi Parlamenterler Meclisi, mahremiyet hakkını "kişinin en az müdahale ile kendi hayatını yaşama hakkı olarak" tanımlamıştır ${ }^{4}$. Ancak

3 SCHABAS, s. 369.

4 Resolution 428 (1970) Containing a declaration on mass communication media and human rights, (http://assembly.coe.int/nw/xml/XRef/Xref-XML2HTML-en. 
günümüzde özel hayata saygı hakkı, kişinin başka bireylerle ilişki kurmasını ve bu ilişkileri geliştirmesini de konu edinecek kadar geniştir5. Dolayısıyla madde 8'i gerek tüm özne türleri bakımından gerekse çocuklar bakımından ele alan akademik çalışmalarda özel yaşama saygı hakkını ifade etmek üzere mahremiyet hakkının kullanılması yerinde değildir. Belirtilen nedenlerden dolayı, çalışmamızda Avrupa İnsan Hakları Sözleşmesi'nin de benimsemiş olduğu "özel yaşama saygı hakkı" kavramı kullanılacaktır.

\section{Avrupa İnsan Hakları Sözleşmesi’nin 8. Maddesi Kapsamında Özel Yaşama Saygı Hakkı}

Özel yaşama saygı hakkı, tarihsel geçmişi çok eskilere dayanmayan, ortaya çıkışı diğer haklara nazaran yeni olarak değerlendirilen haklardan birisidir. Nitekim bu hakka yer veren ilk metin olarak, 1890 tarihinde bir dergide avukat Samuel D. Warren ile hukukçu ve daha sonrasında Amerika Yüksek Mahkemesi hâkimi olan Louis D. Brandeis tarafindan yayınlanan "The Right to Privacy" yani "Mahremiyet Hakkı" adlı makale gösterilir'. İlgili makalede, genel olarak basının ortaya çıkması, fotoğraf çekmenin yaygınlaşması ve kişilerin özel yaşamları hakkında haberler yapılmasına karşı bir hukuki korumanın sağlanması gerektiği, bahsedilen korumanın da ancak mahremiyet hakk1 ya da yalnız birakılmaya hak (let to be alone) ile sağlanabileceği dile getirilmiştir? ${ }^{7}$ Günümüzde ise özel yaşama saygı hakk1, bu çalışmada dile getirilen mahremiyet hakkından çok daha geniş bir kapsama sahiptir.

1800lü yıllarda henüz gelişme evresinde olduğu görülen ve sınırlı bir şekilde ele alınan bu hak, günümüzde pek çok uluslararası insan hakları düzenlemesinin konusu olmuştur. Önceden belirtmek gerekir ki, ilgili hak nezdinde insan hakları düzenlemelerinde bir kavramsal birliğin olmadığ gözlenir. Evrensel İnsan Hakları Bildirisi'nin 12. maddesi, Medeni ve Siyasi Haklar Sözleşmesi’nin 17. maddesi ve Amerikan İnsan Hakları Sözleşmesi'nin 11. maddesi ilgili hakk1 "right to privacy" yani mahremiyet hakk1 olarak düzenlemiştir". Avrupa İnsan Hakları Sözleşmesi'nin 8. maddesinde ise "right

asp?fileid=15842\&lang=en., erişim: 05.11.2019).

5 Von Hannover/Almanya, Başvuru No. 59320/00, 03.06.2004, para. 50.

6 ÖNCÜ, s. 83; GÜMÜŞ, s. 147; SALİHPAŞAOĞLU, s. 229.

7 WARREN/BRANDEIS, s. 195.

81981 tarihli Afrika İnsan ve Halkların Hakkı Şartı'nda ise özel yaşama saygı hakkına ilişkin herhangi bir düzenleme yoktur. 
to respect for private and family life" yani özel ve aile yaşamına sayg hakk1 başlığ 1 altında özel yaşama saygı hakkı olarak düzenlenmiştir. İlgili düzenleme şu şekildedir:

1. Herkes, özel ve aile yaşamına, konutuna ve haberleşmesine saygı gösterilmesi hakkına sahiptir.

2. Bu hakkın kullanımına, yasa uyarınca olması ve ulusal güvenlik, kamu emniyeti ya da ülkenin ekonomik refahı, düzensizliğin ya da suçun önlenmesi, să̆lı̆̆ın ya da ahlakın korunmast ya da başkalarının hak ve özgürlüklerinin korunması için, demokratik bir toplumda gerekli olanlar dışında, kamusal bir makam tarafindan müdahale edilmeyecektir. ${ }^{9}$

Düzenlemeden de anlaşılacağı üzere söz konusu madde içerisinde, kenar başlı̆̆ından farklı olarak çeşitli değerlerin korunması söz konusudur. Her biri farklı birer hak olarak nitelendirilen bu değerler, "özelyaşama saygı hakkl", "aile yaşamına saygı hakkı", "konuta saygı hakkı" ve "haberleşmeye saygı hakkı" olarak adlandırılır ${ }^{10}$. Bu haklara ilişkin herhangi bir tanım madde metninde yer almaz. İlgili kavramlara ilişkin herhangi bir tanımın olmaması, Avrupa İnsan Hakları Mahkemesi'nin 8. maddeyi geniş bir şekilde yorumlamasına imkân tanımıştır. Öyle ki, Mahkeme tarafindan "özel yaşam”, "aile yaşamı", "haberleşme" ve "konut" kavramları otonom kavram olarak nitelendirilerek, dört hakkın kapsamı içtihatlar yoluyla belirlenmiştir. Bu belirleme yapılırken, ilgili kavramların otonom niteliği göz önünde bulundurularak dinamik yorum metodu kullanılmış ve pek çok hukuksal menfaat bu kapsamda koruma altına alınmıştır. Her ne kadar farklı birer hak olarak adlandırılsalar da, bu dört hakkı birbirinden ayrı bağımsız bir şekilde ele almak da mümkün değildir. Nitekim birinin koruduğu değer, diğer hakkın içine girebilmektedir ${ }^{11}$. Örneğin, iletişimi hukuka aykırı bir şekilde dinlenen kişilerin, hem özel yaşamı hem de haberleşme hakkı ihlal edilmiş olmaktadır ${ }^{12}$.

Her ne kadar birbirlerinden kesin bir şekilde ayrılamayacak nitelikte olsa da, düzenlemeden de anlaşılacağı üzere özel yaşama hakkının diğer haklardan ayrı olarak bağımsız bir alanının varlığı Avrupa İnsan Hakları Mahkemesi tarafından kabul edilmiştir. Çalışmamızın da konusunu oluşturan

\footnotetext{
9 GEMALMAZ, s.11-12.

10 DOĞRU/NALBANT, s. 1; GÖZÜBÜYÜK/GÖLCÜKLÜ, s. 330; ÖNCÜ, s. 301.

11 GRABENWARTER, s. 184.

12 GÜMÜŞ, s. 149.
} 
bu hakka ilişkin Avrupa İnsan Hakları Mahkemesi kesin, sınırları belirlenmiş herhangi bir tanımda bulunmamıştır ${ }^{13}$. Ancak Mahkeme, bu hakkın kapsamına ilişkin çıkarımlarda da bulunmuştur. Mahkeme öncesinde faaliyet gösteren Komisyon'a göre, "özel yaşam" kavramı, bireyin iç alanı ya da giz alanı ile sınırlanamaz ve bu alanların dişında kalan dış dünyanın özel yaşamın tamamen dişında tutulması halinde hakka yönelik aşırı kısıtlayıcı bir durumun çıkarılacağı belirtilmiştir ${ }^{14}$. Dolayısıyla özel yaşama saygı hakkı, mahremiyet hakk1, dilediğince yaşama hakk1, yalnız bırakılmaya hak ya da aleniyetten korunma hakkından ibaret olmayan, bunların ötesinde bireylerin başka bireylerle duygusal alanı da kapsayacak şekilde ilişki kurması ve geliştirmesini kapsamına alan bir haktır ${ }^{15}$. Diğger bir deyişle, özel hayata saygı hakkı, başka bireylerle ilişki kurmayı ve bu ilişkileri geliştirmeyi de kapsar ${ }^{16}$ ve bireylerin başka bireylerle olan etkileşimi özel yaşama saygı hakkının konusuna girer ${ }^{17}$. Örneğin, mesleki yaşam ${ }^{18}$, ticari faaliyet alanlar $1^{19}$ da bu hakka dahildir.

Buradan hareketle Avrupa İnsan Hakları Mahkemesi, çeşitli hukuksal menfaatleri özel yaşama saygı hakkına dâhil etmiştir. Mahkeme'nin içtihatları incelendiğinde, bireyin fiziksel ve zihinsel bütünlüğ̈ hakk1 kapsamında tıbbi müdahaleler, bedenin şiddetten korunması, rızaya dayalı bedene zarar verme eylemleri, sağlıklı bir çevrede yaşama hakkı; kişisel kimliğine ilişkin olarak isim veya soy isim hakkı, cinsel kimlik ${ }^{20}$, geçmişi hakkında bilgi sahibi olma hakk1, fiziksel görünüm, cinsel tacizden korunma, vatandaşlık, şeref ve şöhrete saygı hakk1; üreme ve kürtaj hakkı; seyahat ve dolaşım özgürlüğ̈̈ gibi konular özel yaşama saygı hakkı kapsamında korunmaktadır.

Özel yaşam kavramının norm alanı bu şekildeyken, hakkın Mahkeme içtihatları aracılığıyla pozitif yükümlülükler doğurduğu da hüküm altına alınmıştır. Genel olarak ya da özel yaşam kapsamında pozitif yükümlülüklerin

\footnotetext{
13 MOWBRAY, s. 488.

14 Niemietz/Almanya, Başvuru No. 13710/88, 16.12.1992, para. 29.

15 X/İzlanda, Başvuru No. 6825/74, 18.05.1976; SCHABAS, s. 369.

16 Von Hannover/Almanya, Başvuru No. 59320/00, 03.06.2004, para. 50.

17 S. ve Marper/Birleşik Krallık, Başvuru No.30562/04, 30566/04, 04.12.2008, para. 66.

18 Barbulescu/Romanya, (BD) Başvuru No. 61496/08, 05.09.2017, para. 71; Antovic and Mirkovic/Karadağ Başvuru No. 70838/13, 28.11.2017, para. 42.

19 Satakunnan Markkinapörssi Oy and Satamedia Oy/Finlandiya (BD), Başvuru No.931/13, 27/06/2017, para. 130

20 HERINGA/ZWAAK, s. 666.
} 
kapsamının belirlenmesi veya tanımının yapılması oldukça güçtür. Bunun nedeni, pozitif yükümlülüklere ilişkin genel bir teorinin olmamasıdır. $\mathrm{Bu}$ hususta Mahkeme, özel yaşama ilişkin pozitif yükümlülükleri her somut olayın şartlarına göre belirlemektedir. İlgili belirleme yapılırken, taraf devletlere tanınan takdir yetkisine de saygı duyulmakta ve taraf devletlerin yerine geçerek karar vermekten de kaçınılmaktadır ${ }^{21}$.

Özel yaşama saygı hakkı kapsamında, hakkın içinde geçen "saygı" kavramından dolayı, 8. maddenin taraf devletlere yüklediği birinci yükümlülük esasen sayg1 gösterme yükümlülügüu diğer bir deyişle müdahale etmeme yükümlülüğüdür. $\mathrm{Bu}$ çerçevede, bireylerin özel yaşamlarının kamu ajanlarının keyfi müdahalelerine karşı korunması devletlerin birincil negatif yükümlülügüüür. Aynı kavramdan yola çıkarak ve taraf devletlerin özel yaşama saygı hakkına ilişkin dokunmama ya da müdahale etmeme şeklindeki olumsuz edim türlerinin yetersizliği karşında, ilgili hakkın pozitif yükümlülükler doğurduğu da Mahkeme tarafindan kabul edilmiştir ${ }^{22}$. Madde kapsamında taraf devletlerin pozitif yükümlülükleri her somut olayın koşulları çerçevesinde belirlenir ve sınırlı sayıda değildir. Ancak iç hukukta hakkın ihlalinin önlenmesi amaciyla yasal, yargısal ve idari tüm düzenlemelerin yapılması gerekir. İhlal gerçekleşmişse etkili soruşturmanın başlatılması gerekir. Bu gibi önlemlerin alınmaması pozitif yükümlülükleri ihlal eder ${ }^{23}$.

Özel yaşama saygı hakkı mutlak bir hak değildir. Maddenin ikinci fıkrasından da anlaşılacağı üzere, hukuka uygunluk taşıması halinde sınırlandırılabilir bir haktır. Hakkın sınırlandırılması ancak hukuka uygunluk kriterleri çerçevesinde söz konusudur. Hukuka uygun ya da meşru sınırlandırma ise ancak ikinci fikrada sıralanan ölçütlerle yapılmaktadır. Mahkeme özel yaşama saygı hakkına yönelik sınırlandırmaları incelerken, öncelikle hakka bir müdahalenin olup olmadığını tespit etmektedir. Bir müdahalenin varlığ doğrudan madde 8'i ihlal etmez. Bu müdahale ikinci fikrada aranan kriterleri taşıyorsa hukuka uygun bir müdahaledir. Ancak bu kriterleri taşımıyorsa hukuka aykırı bir müdahaledir ve madde 8 'i ihlal eder ${ }^{24}$. İkinci fikraya bakıldığında, fikranın "bu hakkın kullanımına, yasa uyarınca olması ve ulusal güvenlik, kamu emniyeti ya da ülkenin ekonomik refahı, düzensizliğin ya da

\footnotetext{
21 XENOS, s. 5.

22 Markckx/Belçika, Başvuru No. 6833/74, 13.06.1979, para. 31.

23 HARRIS/O'BOYLE/WARBRICK, s. 535-536.

24 ÖZDEK, s. 222.
} 
suçun önlenmesi, sağlığın ya da ahlakın korunması ya da başkalarının hak ve özgürlüklerinin korunması için, demokratik bir toplumda gerekli olanlar dışında, kamusal bir makam tarafindan müdahale edilmeyecektir" ş̧eklinde düzenlendiği görülür. İlgili düzenleme gereğince, özel yaşama saygı hakkına bir müdahalenin öncelikle kanuni bir dayanağının olması gerekir. Bu hususta ikinci şart ise, müdahalenin ikinci fikrada düzenlenmiş meşru amaçlara ulaşmak için yapılması gerekliliğidir. Üçüncü olarak ise müdahalenin demokratik bir toplumda gerekli olmasıdı2 ${ }^{25}$. Ancak bu şartları taşıyan bir müdahale hukuka uygundur ve hakkı ihlal etmez.

\section{IV. Çocuğun Özel Yaşamına Saygı Hakkı}

Uluslararası insan hakları sözleşmelerinin bir kısmında, özellikle çocukların haklarını özel olarak düzenleyen sözleşmelerde, çocuğun özel yaşamına saygı hakk1 açık bir şekilde düzenlenmiştir. Örneğin, Birleşmiş Milletler Çocuk Hakları Sözleşmesi'nin 16. maddesi, "Hiçbir çocuğun özel yaşantısina, aile, konut ve iletişimine, onur ve itibarına keyfi ya da hukuka aykırt şekilde müdahalede bulunulamaz. Çocuğun bu tür müdahale ve saldırılara karşı yasa tarafindan korunmaya hakkı vardır" şeklindeki düzenlemeyle çocuğun özel yaşamına saygı hakkını açıkça düzenlemiştir ${ }^{26}$. Yine ilgili Sözleşmenin 40. maddesinin 2. fikrasının (vii) bendi, çocukların, "Kovuşturmanın her aşamasında özel yaşamın gizliliğine tam saygı gösterilmesine hakkı olduğunu" düzenlemiştir. Bölgesel alanda geçerli olan Afrika Çocuk Hakları ve Esenliği Şartı'nın "Mahremiyetin Korunması" başlıklı 10. maddesi de, "Ebeveynlerin ya da yasal açıdan çocuğu korumakla sorumlu kişilerin çocuklarının davranışları üzerinde makul ölçüdeki denetim hakkı saklı kalmak şartıyla, hiçbir çocuk, özel yaşamına, aile yaşamına, konuta ve haberleşmeye yönelik keyfi ya da hukuka aykırı müdahaleye yahut şerefine ya da şöhretine yönelik saldırılara maruz bırakılamaz. Çocuk, bu tür müdahale ya da saldırılara karşı yasayla korunma hakkına sahiptir." şeklindeki düzenlemeye yer vermiştir. Böylece Afrika bölgesinde çocuğun özel yaşamına saygı hakkı açık bir şekilde dile getirilmiştir.

Avrupa Bölgesine bakıldığında ise, Avrupa İnsan Hakları Sözleşmesi’nde özel olarak çocuk haklarına yer verilmemiştir. Çocuk haklarına Avrupa İnsan

25 HARRIS/O'BOYLE/WARBRICK, s. 532.

26 Doktrindeki bir görüşe göre, Çocuk Hakları Sözleşmesi'nin etkisi, kamusal ve özel alana ikilemini sorgulamak ve çocukların haklarını ailelerin haklarından ayırmayı; çocukların, hem ebeveynlerine hem de devlete karşı haklara sahip bağımsız aktörler olmasını sağlamaktır. CASS, s. 142. 
Hakları Sözleşmesi'nde açıkça yer verilmemesine ilişkin çeşitli fikirler de ileri sürülmüştür. Bu fikirlere göre, Sözleşmede düzenlenen medeni ve siyasi haklar zaten çocuklar için de geçerlidir ve ayrıca çocuklara vurgu gereksizdir. Ayrıca çocuk hakları Avrupa Sosyal Şartı'nda detaylı bir şekilde düzenlenmiştir ve Avrupa Konseyi çocuk haklarına özgülenmiş bir dizi belge kabul etmiştirir ${ }^{27}$. $\mathrm{Bu}$ görüşlere karşı olarak, Avrupa bölgesinde çocuk haklarının detaylı bir şekilde ele alınmaması gereğine ilişkin ileri sürülen bu gerekçelerin yeterli olmadığı ve Avrupa İnsan Hakları Sözleşmesi'ne eklenecek bir protokol ile çocuk haklarının detaylı bir şekilde düzenlenmesi gereği vurgulanmıştır ${ }^{28}$.

Her ne kadar Avrupa İnsan Hakları Sözleşmesi'nde özel olarak çocuk haklarına yer verilmemiş olsa da, Sözleşmesi'nin 1. maddesi, Sözleşmede düzenlenen hak ve özgürlüklerden "herkesin" yararlanmas1 gereğini vurgular. Bu düzenlemenin yanı sıra Sözleşme'nin 14. maddesi, Sözleşmede düzenlenen hak ve özgürlüklerden yararlanmanın hiçbir ayrımcılık gözetilmeden sağlanması gereğini hüküm altına alır. Böylece yaşa bağlı olarak Sözleşmede düzenlenen haklardan yararlanmada ayrımcılık yapılmasını yasaklar. Bahsedilen düzenlemeler neticesinde, Avrupa İnsan Hakları Sözleşmesi sisteminde kural olarak çocuklar yetişkinlerle aynı haklara sahiptir ve Sözleşmede düzenlenen haklarından yararlanırken ayrımcılığa maruz kalmamalıdırlar. Bu kapsamda Avrupa İnsan Hakları Sözleşmesi'nin 8. maddesinde düzenlenen özel yaşama saygı hakkı çocuklar için de geçerlidir. Diğer bir deyişle, Avrupa İnsan Hakları Sözleşmesi kapsamında çocuklarda özel yaşamlarına saygı gösterilmesi hakkına sahiptir. Ancak çocukların özel yaşamlarına ilişkin birtakım durumlar yalnızca 8 . maddenin koruması altında değildir. Özellikle adil yargılanma hakkını düzenleyen 6. madde kapsamında da çocukların özel yaşamlarına ilişkin tedbirler söz konusudur. Yargılama esnasında çocukların özel yaşamlarına saygı Sözleşme'nin koruduğu temel değerlerden birisi olarak 6 . maddede yer alır.

Çocukların özel yaşamlarına sayg1 hakk1, Avrupa İnsan Hakları Mahkemesi'nin çeşitli kararlarına konu olmuştur. İlgili kararlar, çocuk fotoğraflarının ya da videolarının çekilmesini veya yayınlanmasını, çocukla ilgili bilginin internette açıklanmasını ya da kişisel verilerinin hukuka aykırı bir şekilde saklanmasını konu edinir. Bu gibi durumların yanı sıra yasal ve yargısal işlemlerin konusu olan çocukların özel yaşama saygı hakkının adil

\footnotetext{
27 ALSTON/TOBIN, s. 17.

28 ALSTON/TOBIN, s. 17.
}

434 Ankara Hacı Bayram Veli Üniversitesi Hukuk Fakültesi Dergisi C. XXIV, Y. 2020, Sa. 2 
yargılanma hakkı kapsamında ele alındığı görülür ${ }^{29}$. Çalışmanın devamında ilgili konular detaylı bir şekilde açıklanmaya çalışılacaktır.

\section{A. Fotoğraf veya Videonun Konusu Olan Çocuklar}

Kişilerin başkalarının fotoğraflarını o kişinin rızası olmadan çekmesi, saklaması veya kamuyla paylaşması özel yaşama saygı hakkına ilişkin ortaya çıkan önemli hukuki meselelerdir. Bu hususta Avrupa İnsan Hakları Mahkemesi, kişinin adı, fotoğrafı veya fiziksel ve psikolojik bütünlük gibi kişisel kimliğine ilişkin hususların özel yaşam kapsamında ele alınması gerektiğini belirtir ${ }^{30}$. Mahkeme'ye göre, bir kişinin görüntüsünü ortaya koyan fotoğraflar, kişiliğin kendine has özelliklerini ortaya koyar ve kişinin benzerlerinden farklılaşmasını sağlar. Kişinin görüntüsünü (imajını) koruma hakk1 (right to the protection of one's image) olarak da adlandirılan bu hak, kişisel gelişiminin temel unsurlarından birisidir ve bu hak, bireyin kendi fotoğrafları üzerinde tam bir hâkimiyet hakkı sağlar. Bu bağlamda kişi, yayınlanmayı reddetme hakkı da dâhil olmak üzere, görüntülerinin kullanımını kontrol etme hakkına sahiptir ${ }^{31}$. Bu başlık altında çalışmamız açısından dikkat edilmesi gereken ise, fotoğrafları çekilen kimsenin çocuk olması durumunda, onlara Mahkeme tarafından daha fazla korumanın sağlanıp sağlanmadığıdır.

Avrupa İnsan Hakları Mahkemesi'nin, bir çocuğun fotoğrafının rıza unsuru olmadan çekilmesini madde 8 kapsamında ele aldığ 1 dava söz konusu olmuştur. Bu dava, Yunanistan’a karşı açılan Reklos ve Davourlis/Yunanistan davasıdır ${ }^{32}$. İlgili dava, çocuğun ve ailesinin rızası alınmadan çocuklarının fotoğraflarını çeken fotoğrafçı aleyhinde yasal işlemlerin yerel mahkemeler tarafından reddedilmesi neticesinde devletin çocuk haklarını koruyamadığına

29 İlgili kararları doktrinde Kirsty Hughes beş gruba ayırarak ele almıştır. Yazara göre, çocuğun özel yaşamına saygı hakkını ilgilendiren birinci grup kararlar, yasal işlemlerde yer alan ya da bu işlemlerden dolaylı olarak etkilenen çocukların mahremiyet haklarını ele almaktadır. İkinci grup kararlar, çocukların tanıtımlarını; üçüncü grup kararlar çocuk fotoğraflarının çekilmesini veya yayınlanmasını içeren kararlardır. Dördüncü grup kararlar, bir çocukla ilgili bilgilerin internette açıklandığı durumları; beşinci grup kararlar ise tıbbi gizliliği konu edinir. Yazar bu şekilde bir ayrımı özel yaşama saygı hakkının genel konularını ele alarak yapmış olduğu açıktır. Nitekim tarafımızca yapılan araştırmada Avrupa İnsan Hakları Mahkemesi'nin çocukların tıbbi gizliliğine ilişkin bir kararına henüz rastlanmamıştır. Yazar da ilgili makalesinde açmış olduğu başlığın altına böyle bir karar örneği eklememiştir.

30 Von Hannover/Almanya, Başvuru No. 40660/08, 60641/08, 07.02.2012, para. 95.

31 Reklos ve Davourlis/ Yunanistan, Başvuru No. 1234/05, 15.04.2009, para. 40; Von Hannover/Almanya, Başvuru No. 40660/08, 60641/08, 07.02.2012, para. 95.

32 Reklos ve Davourlis/Yunanistan, Başvuru No. 1234/05, 15.04.2009. 
ilişkin şikâyeti konu edinir. Başvuruya konu olaylar ise şöyledir: Başvuranlar, yeni doğmuş bir bebeğin ebeveynleriydiler ve hastanede çalışan profesyonel bir fotoğrafçı, bebeğin kaldığı ünitede fotoğraflarını çekerek, kendilerine para karşılığ1 satmayı teklif etmiştir. Başvuranlar, rızası alınmadan çekilen fotoğraflara itiraz etmiş ve fotoğrafçının negatifleri teslim etmesini talep etmişlerdir. Fotoğrafçı ise fotoğrafların negatiflerini teslim etmeyi reddetmiştir. Bunun üzerine anne ve baba fotoğrafçının çocuklarının kişilik haklarını ihlal ettiği iddiasıyla yasal işlem başlatmıştır. Bu iddia Yunanistan Yüksek Mahkemesi tarafindan "çok belirsiz" olarak nitelendirilip, reddedilmiştir ve bunun üzerine ebeveynler, Avrupa İnsan Hakları Mahkemesi'ne başvuruda bulunmuşlardır ${ }^{33}$. Başvuranlar, çocuğun özel hayatına saygı hakkına hukuka aykırı bir müdahale olduğunu iddia etmişlerdir ${ }^{34}$. Yunanistan Hükümeti ise, ilgili davada Avrupa İnsan Hakları Sözleşmesi'nin 8. maddesinin bu davada uygulanabilirliğine itirazda bulunmuştur. Hükümete göre, fotoğraflar yayınlanmadığından dolayı bebeğin özel yaşamının söz konusu olmadığ1 ileri sürülmüştür. Ayrıca, fotoğraflar kamuyla paylaşılmadığı için bebeğin görüntüsünün ticari bir sömürüsünün olmadığı ve sadece bir günlük olan bebeğin zihinsel olgunluğu, kişilik haklarının ihlal edildiğini hissetmesi için yeterince gelişmediği ileri sürülmüştür ${ }^{35}$.

Mahkeme, kararını gerekçelendirirken öncelikle davanın kapsamını sınırlayarak işe başlamıştır ve başvuranlar tarafından ileri sürülen kişinin görüntüsünün korunması hakkının, bireyin müdahalenin farkında olup olmadığına bağlı olduğuna ilişkin genel bir soru ile ilgilenmeyeceğini açıkça belirtmiştir. AİHM görevini, fotoğrafların ebeveynlerin önceden rızası olmadan çekilmesi ve negatiflerin fotoğrafçıda kalması eylemlerinin bebeğin, Sözleşme'nin 8. maddesi ile güvence altına alınan özel yaşama saygı hakkına müdahale edip etmediği ve yerel mahkemelerin başvuranların oğlunun özel yaşamına yeterli koruma sağlayıp sağlamadığının tespiti olduğunu belirtmiştir ${ }^{36}$.

Mahkeme, kararına AİHS'nin 8. maddesinin kimlik hakkını ve kişilik veya kişisel özerklik anlamında, kişisel gelişim hakkını kapsadığını belirterek başlamıştır. Bu ilkelerin AİHS'in 8. maddesinin temeli olduğunu kabul eden

\footnotetext{
33 HUGHES, Photograps, s. 163.

34 Reklos ve Davourlis/Yunanistan, Başvuru No. 1234/05, 15.04.2009, para. 29.

35 Reklos ve Davourlis/Yunanistan, Başvuru No. 1234/05, 15.04.2009. para. 30-31.

36 Reklos ve Davourlis/Yunanistan, Başvuru No. 1234/05, 15.04.2009, para. 34.
} 
AİHM, bir kişinin görüntüsünün, kişisel gelişimininin en temel unsurlarından biri olduğunu, bu nedenle bireyin görüntüsünü kontrol edebilmesinin çok önemli olduğunu vurgulamıştır. Kişi, yalnızca birinin görüntüsünü yayınlanmasına izin vermeyi reddetmekle kalmamalı; aynı zamanda görüntüsünün başka bir kişi tarafından alınması, korunması veya çoğaltılmasını reddetme firsatına sahip olmalıdır. Mahkeme'ye göre bir kişinin görüntüsü, kişiliğinin kendine has özelliklerini ortaya koyar ve kişiyi diğer kimselerden ayırdığı için kişiliğinin temel özelliklerinden birini oluşturur. Kişinin görüntüsünü koruma hakkı bu nedenle kişisel gelişimin temel bileşenlerinden birisidir ve bu, kendi görüntüsünün kullanımını kontrol etme hakkını öngörür. Çoğu durumda bu kullanımı kontrol etme hakkı, bir bireyin görüntüsünü yayınlamayı reddetmeyi içerirken, bireyin görüntüsünü başka bir kişi tarafindan kaydetme, koruma ve çoğaltmasına itiraz etme hakkını da kapsar. $\mathrm{Bu}$ nedenle çekilen resim yayınlandığında ya da yayınlanmadığında etkili bir korunma için ilgili kişinin rızasının alınması gerekir. Aksi takdirde, üçüncü bir kişinin elinde temel bir kişilik niteliği korunacak ve ilgili kişi görüntünün daha sonraki kullanımı üzerinde hiçbir kontrol sahibi olmayacaktır. ${ }^{37}$

$\mathrm{Bu}$ ilkeleri gerçeklere uyguladıktan sonra, AİHM, fotoğraf çekme eyleminin ve bu fotoğrafların saklanmasının, çocuğun 8 . maddede düzenlenen hakkını ihlal ettiğine hükmetmiştir. Mahkeme'ye göre, ilgili kişi küçüktür ve görüntüsünü koruma hakkının kullanılması ebeveynlerin uhdesindedir. Bunun sonucunda ise, hakkın kullanımı için başvuranların oğullarının resimlerinin çekilmesine önceden rıza göstermeleri gerekir. Bu nedenle Mahkeme, fotoğrafların çekilmesi için rızayı gerekli kılmıştır ve başvuru sahibi küçük olduğu için gerekli olan ebeveyn rızasıdır ${ }^{38}$. Fotoğrafların içeriğgi zararsız ve hakaret içerikli olmasa da, bebeğin görüntüsü, ilgili kişinin ve/ veya ailesinin rızası olmadan daha sonra kullanılma olasılığı ile fotoğrafçının elinde muhafaza edilmektedir. Yerel mahkemelerde, başvuranların, oğlunun fotoğrafinın çekilmesine ve fotoğrafçı tarafından alıkonulmasına rıza göstermediği gerçeğini hesaba katmamışlardır. Yukarıda belirtilenler ışığında, Mahkeme, Yunan mahkemelerinin mevcut davada başvuranların oğlunun özel hayatını koruma hakkını yeterince garanti etmediğini tespit etmiştir. $\mathrm{Bu}$ nedenle, Sözleşme'nin 8. maddesinin ihlaline hükmetmiştir.

\footnotetext{
37 Reklos ve Davourlis/Yunanistan, Başvuru No. 1234/05, 15.04.2009, para. 40.

38 KINDT, s. 193.
} 
Dikkat edileceği üzere ilgili dava, küçüğün fotoğraflarının kendi ailesi dışında bir başkası tarafından çekilmesi üzerinedir ve kararda, küçüğün fotoğraflarının çekilirken rızanın olması gereği belirtilir. Karar neticesinde anlaşılmaktadır ki, küçük adına bu rızayı gösterecek olan kişiler de çocuğun ailesidir. Ailesi tarafindan kendi çocuklarının fotoğraflarının çekilmesi durumunda ise çocuğun özel yaşama saygı hakkına müdahalenin gerçekleşip gerçekleşmeyeceğine ilişkin sorunun cevabi ise bu karar sonucunda ortaya çıkmamaktadır. Elbette aileler kendi çocuklarının küçüklük hatıralarını saklamak amacıyla fotoğraflarını çekebilirler. Ancak günümüzde bu durum farklı bir hal almıştır. Sosyal medya aracılığıyla pek çok ebeveyn, çocuğunun fotoğrafını yaygın bir şekilde kamuyla paylaşmaktadır. Örneğin Amerika'da, çocukların yüzde doksan ikisinin, iki yaşına varmadan önce internet üzerinde bilgilerinin aileler tarafindan çevrimiçi olarak oluşturulduğu ve pek çok fotoğrafinın paylaşıldığı gözlenmiştir ${ }^{39}$.

Aileler tarafından paylaşılan bu fotoğraflar kimi zaman çocukları duştayken ya da çıplak haldeyken veyahut çocuğu küçük düşürücü durumları da konu edinmektedir. Kimi zaman ticari kazanç elde etme amacıyla da paylaşımlar yapılmaktadır. Bu gibi paylaşımlardan çocuğun rahatsız olacağı bir gerçektir. 8-12 yaşlar arasındaki çocuklar nezdinde yapılan bir araştırma da bunu teyit eder niteliktedir. Bu yaş grubundaki çocuklar, aileleri tarafından çekilen ve paylaşılan fotoğraflardan rahatsız olduğunu dile getirmişlerdir. Örneğin bir çocuk annesinin kafasının üstüne hamstır koyarak kendisini çektiğini ve çok utandığını belirtmiştir. Diğer bir çocuk kendisi duştayken şarkı söylediği esnada annesinin kendisini çıplakken kaydettiğini ve utandığını belirtmiştir ${ }^{40}$. Çocuklarını en mahrem haldeyken kaydedip, sosyal medya aracılığıyla kamuyla paylaşmak aynı zamanda onları cinsel istismarın kurbanları haline getirme tehlikesini de taşır ${ }^{41}$. Dolayısıyla çocuğun rıza gösterme yetisine sahip olduğu ve olamadığ 1 durumlarda, ailelerin de çocuklarının fotoğraflarını çekip kamuyla paylaşmasında özenli olmaları gerekir. Aksi halde çocuklarının kişisel gelişimleri olumsuz yönde etkilenir ve bu durum özel yaşama saygı hakkı kapsamında görüntüsünü koruma hakkını ihlal eder.

39 BESSANT, s. 7.

40 Children's Commissioner, 'Life in Likes: A report into social media use among 8-12 year olds', January 2018, (www.childrenscommissioner.gov.uk, erişim: 04.11.2019); GLIGOIJEVIC, s. 203.

${ }_{41}$ K.U./Finlandiya, Başvuru No. 2872/02, 02.03.2009, para. 46. 
Çocuğun görüntüsünün korunması hakkının ihlal edilmesinin yanı sıra, kendi ailesinin yanında ve yaşamını sürdürdüğü evinde güvende hissetmesi çocuğun en doğal hakkıdır. Her zaman ve her durumda ailesi tarafından fotoğraflanacağ 1 veya kaydedileceği şüphesiyle yaşamak onlar için oldukça zordur. Dolayısıyla bu gibi durumlarda aileler eliyle çocuklarının özel yaşamlarına saygı hakkı kapsamında kişilik haklarına müdahale gerçekleşir. Devletlerin çocukların rızası olmadan aileleri tarafından evin içinde dahi olsa fotoğraflanması ya da videoya çekilmesi halinde, çocukların başvurabileceği yargısal yolları iç hukuklarında düzenlemeleri gerekir. Aksi halde özel yaşama saygı hakkı ihlal edilir. Bu husus, çocuğun kendisinin rızası olmadan kendi evinde üvey babası tarafından videoya kaydedildiği Söderman/İsveç davasında netleşmiştir.

İlgili dava, 14 yaşındaki kız çocuğunun banyoda çıplak bir haldeyken üvey babasının gizlice kendisini filme almasını ve bunu fark eden genç kızın, söz konusu dönemde üvey babanın eylemlerine ilişkin herhangi bir yaptırım öngörmeyen İsveç hukuk sisteminin kişilik hakkının ihlal edilmesine (violation of her personal integrity) karşı kendisini koruyamadığ konusundaki şikâyetini konu edinmektedir ${ }^{42}$. Mahkeme söz konusu olayda, üvey babanın eyleminin başvurucunun kişilik hakkının ihlaline yol açtığını belirtmiştir ${ }^{43}$. Üstelik başvurucunun on sekiz yaşından küçük olması, olayın başvurucunun kendisini güvende hissetmesi gereken evinde gerçekleşmiş olması ve eylemi gerçekleştiren kişinin, başvurucunun yetkisi altında olduğu ve güvenmesi beklenen üvey babası olması nedeniyle ağırlaştırılmış sebeplere sahiptir ${ }^{44}$. Ağırlaştırılmış bu sebeplere rağmen, konuyla ilgili İsveç Hukuku'nun yürürlükte olduğu haliyle, başvurucunun özel hayatına saygı hakkını, davalı devletin takdir payına rağmen, Sözleşme'nin 8. maddesinden doğan pozitif yükümlülüklere uygun biçimde güvence altına almamıştır. Nitekim İsveç Hukuku'nda davanın somut koşulları içinde, bahsi geçen kişilik hakkının ihlaline karşı başvurucuya etkili bir koruma sağlayacak ne cezai ne de hukuki bir yol bulunmaktadır ${ }^{45}$. Buradan hareketle Mahkeme, Sözleşme'nin 8. maddesinde düzenlenen özel yaşama saygı hakkının ihlal edildiğine karar vermiştir.

\footnotetext{
42 Söderman/İsveç, Başvuru No. 5786/2008, 12.11.2013.

43 Söderman/İsveç, Başvuru No. 5786/2008, 12.11.2013, para. 86.

44 JACOBS/WHITE/OVEY, s. 417; Söderman/İsveç, Başvuru No. 5786/2008, 12.11.2013, para. 86.

45 Söderman/İsveç, Başvuru No. 5786/2008, 12.11.2013, para. 117.
} 
Kurier Zeitungsverlag und Druckerei GmbH/Avusturya davasinda ise anne ve babanın boşanması sonrasında çocukları üzerinde çekişmeli geçen velayet davasını haber yapan ve bu haberlerde çocuğun kimliğini açıkça belirten ve resmini tanınacak şekilde basan gazetenin tazminat ödemeye mahkûm edilmesi üzerine, ilgili gazete ifade özgürlügünün ihlal edildiğini iddia etmiştir. İlgili dava, madde 8 'de düzenlenen özel yaşama saygı hakkının ihlal edildiği iddiasını taşımamaktadır. Ancak Avrupa İnsan Hakları Mahkemesi, söz konusu davada açıkça 10. madde kapsamında basının sahip olduğu haklar ile 8. maddede yer alan özel yaşama saygı hakkının çatıştığını belirtmiştî ${ }^{46}$. Mahkeme ilgili davada öncelikle demokratik bir toplumda basının özel önemine işaret etmiştir. Basın kamu menfaatlerini ilgilendiren konularda bilgi ve fikir paylaşır. Basının yalnızca bilgi ve fikirleri paylaşma görevi yoktur; aynı zamanda kamu oyununda bu bilgi ve fikirleri alma hakkı vardır. Ancak basının yalnızca genel menfaatleri ilgilendiren konularda fotoğraflar veya makalelerle demokratik topluma katk1 yaptığ1 da kararda belirtilmiştir. Basının, yalnızca belli bir okuyucu kitlesinin merakını tatmin etmek üzere halktan bir kişinin özel hayatına dair ayrıntılı fotoğraf ve makale yayımlaması, söz konusu kişi halk tarafından tanınıyor olsa bile, kamuoyunun genel menfaatlerini ilgilendiren konulara katk1 sağlamak olarak kabul edilemez. Bu gibi durumlarda ifade özgürlüğü daha sınırlı bir şekilde yorumlanmalıdır. Ayrıca reşit olmayan kişilerin korunması açısından madde 8 uyarınca devletlerin yerine getirmesi gereken pozitif yükümlülükler bulunur ${ }^{47}$. Mahkemeye göre söz konusu davada çocuk, kamuya mal olmuş bir kişi değildir. Mahkeme, daha önce kamuoyunda yer almadığından dolayı, ilgili haberlerde çocuğun kimlik bilgilerinin ifşa edilmesi ve çocuğun tanınabilecek halde fotoğraflarının kullanılmaması gerektiğini belirtmiştir ${ }^{48}$. Diğer taraftan, velayet anlaşmazlığının mağduru haline gelen ve kamuoyuna kendi isteğiyle mal olmamış olan ve henüz reşit olmayan bir kişinin özel hayatının, içinde bulunduğu çok hassas durum nedeniyle özel olarak korunma gerektirdiğini de vurgulamıştır ${ }^{49}$. Dolayısıyla ilgili davada, yayınlanan bilgiler 1şığında kamu

46 Kurier Zeitungsverlag und Druckerei GmbH/Avusturya (No.2), Başvuru No. 1593/06, 19.06.2012.

47 Kurier Zeitungsverlag und Druckerei GmbH/Avusturya (No.2), Başvuru No. 1593/06, 19.06.2012, para. 51 .

48 Kurier Zeitungsverlag und Druckerei GmbH/Avusturya (No.2), Başvuru No. 1593/06, 19.06.2012, para. 57.

49 Kurier Zeitungsverlag und Druckerei GmbH/Avusturya (No.2), Başvuru No. 1593/06, 19.06.2012, para. 59 . 
menfaati ile özel yaşamın korunması arasında adil bir denge kurulmadığından yola çıkarak ilgili gazetenin ifade özgürlügünün ihlal edilmediğine karar vermiştir.

\section{B.İnternet Yayınlarının Konusu Olan Çocuklar}

Avrupa İnsan Hakları Mahkemesi'nin çocukların özel yaşamlarına güçlü bir koruma sağladığı alanlardan birisi internet yayınlarıdır. Özellikle internet yayınlarının konusunun çocuk olduğu durumlarda Mahkeme, madde 8'e önem atfetmektedir. Bu konuda içtihadını belirlediği kararı, K.U./Finlandiya ${ }^{50}$ davasıdır. Başvurucu henüz 12 yaşındayken kendisi adına internette bir buluşma sitesinde bir ilan verilmiştir. Bu ilanda, kendisine yol gösterecek kendi yaşında veya daha büyük bir erkekle yakın ilişki kurmak istediği ifadelerine yer verilmiştir. Bu ifadelerin yanı sıra ilanda, erkek çocuğun yaşı ve doğum y1lı, fiziksel özelliklerinin ayrıntılı bir tanımı, resminin olduğu kişisel internet hesapları ve telefon numarası yazılmıştır. Başvuran bu ilandan, kendisiyle tanışmak amacıyla bir erkek tarafından gönderilen mail aracılığıyla haberdar olmuştur. Başvuranın babası, suç duyurusunda bulunabilmek için emniyet güçlerinden ilanı yayınlayan kişinin bilgilerini istemiştir. Bunun üzerine polis, servis sağlayıcıdan ilanı veren kişinin kimlik bilgilerini istemiştir. Ancak servis sağlayıcısı gizlilik yasalarını ihlal edeceği gerekçesiyle bu bilgileri paylaşmayı reddetmiştir. Yerel Bölge Mahkemesi de, servis sağlayıcısının ilan verenlerin kimlik bilgilerini mesleki gizliliğe aykırı şekilde açıklamaya zorlayan yasal bir düzenleme olmamasından dolayı talebi reddetmiştir. Bunun üzerine K.U., Finlandiya mevzuatının kişilerin mahremiyet ihlallerine karşı tazminat yolu ya da cezai yaptırıma ilişkin herhangi bir hukuki yol olmadığı iddiasıyla Avrupa İnsan Hakları Mahkemesi'ne başvurmuştur.

Mahkeme, ilgili davada 8. maddenin uygulanabilirliğine ilişkin herhangi bir tereddüdün bulunmadığını, başvurunun kişinin fiziksel ve psikolojik bütünlüğünü kapsayan bir kavram olan özel yaşama ilişkin olduğunu belirtmiştir ve başvuranın fiziksel ve zihinsel refahı ve genç yaşından dolayı başvuranın kırılganlığına yönelik olası tehdidi göz önünde bulundurarak, özel yaşam kavramının bu yönlerini vurgulamayı tercih edeceğini belirtmiştir ${ }^{51}$. Mahkeme'ye göre, madde 8 kapsamında devletlerin, bireylerin kendi aralarındaki ilişkilerinden doğan özel hayata saygı hakkının ihlaline ilişkin önlem alma yükümlülügü vardır. Bu kapsamda devletlerin etkin soruşturma

\footnotetext{
50 K.U./Finlandiya, Başvuru No. 2872/02, 02.03.2009.

51 K.U./Finlandiya, Başvuru No. 2872/02, 02.03.2009, para. 41.
} 
yapma şeklinde olumlu yükümlülükleri bulunur. Çocuğun fiziksel ve ahlaki refahına yönelik bir tehdit söz konusu ise bu yükümlülük daha da önem taşır. Nitekim söz konusu olaydaki gibi durumlarda çocuklar cinsel istismarın kurbanları olabilmektedir. $\mathrm{Bu}$ nedenle başta çocuklar olmak üzere diğer korunmasız bireyler, özel yaşamlarına yönelik bu tür ciddi müdahalelere karşı etkili caydırma şeklinde devlet tarafından korunmaya hakları vardır. Mahkeme'ye göre her ne kadar ifade özgürlüğ̈ ve iletişimin gizliliği öncelikli ve internet servisi kullanıcıları kendi mahremiyetlerine ve ifade özgürlüklerine sayg1 gösterileceğine dair bir güvenceye sahip olsa da, bu güvence mutlak nitelikte değildir. Suçun ve düzensizliğin önlenmesi, başkalarının hak ve özgürlüklerinin korunması şeklindeki meşru amaçlar bu hakların sınırlarıdır ${ }^{52}$. Buradan hareketle Mahkeme, devletin suçluların isimlerinin açılanmasını yasaklayarak ve etkili bir ceza adaleti süreci uygulamayarak çocuğun fiziksel ve ahlaki refahını korumak için olumlu yükümlülüklerini yerine getirmediğini belirterek 8. maddenin ihlal edildiğine karar vermiştir.

Bir önceki başlıkta Reklos ve Davourlis/Yunanistan kararının devamında tarafimızca dikkat çekildiği gibi, burada da çocuğun bilgilerinin internette paylaşılması eylemini gerçekleştirenin aileler olmadığını, üçüncü kimseler tarafından bu eylemin gerçekleştirildiği görülmektedir. Ancak yukarıda yapılan değerlendirmeler burada da geçerlidir. Aileler tarafından çocuklarının bilgilerinin internet ortamında paylaşılması da çocuğu doğrudan cinsel istismar kurbanı haline getirebilmektedir. Bu nedenle, Mahkeme'nin Söderman/İsveç kararında dikkat çektiği bu durum aileler nezdinde de son derece önemlidir.

\section{Kişisel Verileri Hukuka Aykırı Bir Şekilde Kaydedilen Çocuklar}

Avrupa İnsan Hakları Mahkemesi'nin içtihatları doğrultusunda özel yaşama saygı hakkı kapsamında kişisel veriler de korunur. Mahkeme'ye göre, "özel yaşam" kavramı ayrıntılı bir tanımlamaya müsait olmayan oldukça geniş bir kavramdır ve kişinin fiziksel ve psikolojik bütünlügüne ilişkin birçok menfaat hakkın konusunu oluşturabilir ${ }^{53}$. Bu nedenle, kişinin fiziksel ve sosyal kimliğinin birçok yönü "özel yaşam" kavramına dâhildir ${ }^{54}$. Bu bağlamda kişilerin, "isimleri, cinsiyeti, cinsel yönelimleri, etnik kimliği, kişinin sağlığlyla ilgili bilgiler" gibi unsurlar Mahkeme’ye göre kişisel verilerdir. Kişisel verilerin devletler tarafından kaydedilmesi ve kaydedilen bu bilgilerin

52 K.U./Finlandiya, Başvuru No. 2872/02, 02.03.2009, para. 49.

53 Pretty/Birleşik Krallık, Başvuru No. 2346/02, 29.07.2002, para. 61.

54 Mikulić/Hurvatistan, Başvuru No. 53176/99, 04.09.2002, para. 53. 
daha sonra kullanılması kural olarak doğrudan özel yaşama saygı hakkını ihlal etmez ${ }^{55}$. Ancak hukuka aykırı bir şekilde bu işlemlerin gerçekleşmesi halinde madde 8'in ihlali gerçekleşir. Hukuka aykırılığın tespitinde ise Mahkeme, yetkililer tarafından tutulan kişisel verilerin kaydedildiği ve saklandığı özel koşulları göz önünde bulundurarak, kayıtların nasıl işlendiğini, kullanıldığını ve elde edilen sonuçları göz önünde bulunduracağını belirtmiştir ${ }^{56}$.

Çocukların kişisel verilerinin devlet yetkilileri tarafından hukuka aykırı şekilde saklanması vakası da Mahkeme'nin önüne gelmiştir. İlgili başvuru, S ve Marper/Birleşik Krallık ${ }^{57}$ davasıdır. Söz konusu davada, ilk başvurucu olan S, 11 yaşında iken diğer başvurucu ile beraber soygun eyleminde bulunma teşebbüsüyle suçlanmışlar ve bu kapsamda emniyet güçlerince parmak izleri ve DNA örnekleri alınmıştır. Yürütülen soruşturmada suçsuz bulunmaları neticesinde parmak izlerininve DNAörneklerinin imha edilmesini istemişlerdir. Ancak emniyet güçleri tarafından bu talepleri olumsuz karşılanmış ve iç hukukta dava yoluna gitmişlerdir. Talebe konu işlemleri, İdare Mahkemesi, Üst Mahkeme tarafindan reddedilerek; gerçekleşmemiştir. İç hukuk yollarını tüketen her iki kişide, özel yaşama saygı hakkını düzenleyen 8. maddenin ihlal edildiği iddiasıyla Avrupa İnsan Hakları Mahkemesi'ne bireysel başvuruda bulunmuştur. Burada başvuranlar, parmak izlerinin ve DNA'ların tutulduğu veri tabanının çocuklar üzerinde sosyal damga niteliğini ve psikolojik etkileri olduğunu dile getirmişlerdir ${ }^{58}$. Mahkeme mevcut davada, yetkililer tarafından tutulan parmak izi, DNA ve hücresel örneklerin kişiyi tanımlayan veya tanımlayabilir nitelikte olmalarından hareketle kişisel veri olduğunu tespit ederek incelemesine başlamıştır ${ }^{59}$. Devamında ise, Hükümet tarafından ileri sürülen parmak izi ve DNA bilgilerinin saklanmasının suçlunun tespit edilmesi ve suçun önlenmesi amacına uygun olduğuna karar vermiştir. Ancak müdahalenin demokratik bir toplumda gerekli olup olmadığına ilişkin değerlendirmesinde ise hakkın ihlal edildiğine hükmetmiştir. Bunu yaparken Mahkeme emniyet güçlerince şüphelilere yönelik gerçekleştirilen işlemin çocukların gelişimi ve topluma entegrasyonu üzerindeki olası yıkıcı ve zararlı etkilerini vurgulamıştır ${ }^{60}$. Mahkemeye göre, haklarında herhangi bir suçtan

\footnotetext{
55 Amann/İsviçre (GC), Başvuru No. 27798/95, 16.02.2000, para. 69.

56 Peck/Birleşik Krallık, Başvuru No. 44647/98, 28.04.2003, para. 59

57 S ve Marper/Birleşik Krallık, Başvuru No. 30562/04 ve 30566/04, 04.12.2008.

58 S ve Marper/Birleşik Krallık, Başvuru No. 30562/04 ve 30566/04, 04.12.2008, para. 60.

59 S ve Marper/Birleşik Krallık, Başvuru No. 30562/04 ve 30566/04, 04.12.2008, para. 68.

60 HEPPLE, s. 80.
} 
dolayı hüküm verilmemiş kişilerin verilerinin saklanması sakıncalıdır ve bu durum özellikle küçükler için daha da zararlı olabilir. Nitekim küçüklerin, gelişimleri ve toplumla bütünleşebilmeleri oldukça önemlidir. Bu nedenle haklarında işlem yapılan küçüklerin salıverilmelerinin ardından, kişisel verilerinin yetkililer tarafindan tutulmasından kaynaklanabilecek herhangi bir zarardan dolayı korunmalarına devletlerin özel dikkat göstermesi gerekir ${ }^{61} . \mathrm{Bu}$ nedenle Mahkeme, parmak izlerinin ve DNA örneklerinin alınma işleminin, genel nitelikte ve hükümlüler ile suç isnadı altında olanlar arasında ayrım gözetilmeden yapılmasını Avrupa İnsan Hakları Sözleşmesi’nin 8. maddesine orantısız bir müdahale olarak değerlendirmiş ${ }^{62}$ ve hakkı ihlal ettiğine karar vermiştir. İlgili karar, çocuğun kişisel verilerinin 8. madde kapsamında özel öneme sahip olduğunu göstermesi bakımından oldukça önemlidir.

Kararın verildiği yıllarda, İngiltere nezdinde kişilerin DNA'larının yaygın bir şekilde işlenmesinin devlet pratiği haline gelmiş olduğu da gözlenmiştir. Örneğin, kararın verildiği 2008 yılında Birleşik Krallık nüfusunun yaklaşık \% 6.5'nin yani 4,5 milyon kişinin bilgileri veri tabanına işlenmiştir. Ayrıca, profili oluşturulan kişilerin beşte birinin yani 850.000 kişinin hiçbir zaman bir suçtan dolayı mahkûm edilmediği de görülmüştür ${ }^{63}$. Birleşmiş Milletler Çocuk Hakları Komitesi, İngiltere'de uygulanan DNA veritabanının çocuklar üzerindeki etkisine ilişkin endişelerini dile getirmiştir ${ }^{64}$. Avrupa İnsan Hakları Mahkemesi'nin S. ve Marper kararını ve diğer gelişmeleri takiben 2009 yılında, 10 yaşın altındaki çocukların tüm DNA profilleri veri tabanından silinmiştir ${ }^{65}$.

\section{Adil Yargılanma Hakkı Karşısında Çocuğun Özel Yaşamına Saygı Hakkı}

Adil yargılanma hakk1, AİHS'in 6. maddesinde düzenlenir. Düzenleme gereğince hakkın uygulama alanı, medeni yargılamalar ve suç isnadı altında bulunan kimselere ilişkin yapılan ceza yargılamalarıdır. Söz konusu hak kapsamında kişilerin, mahkemeye erişim hakkı, yasayla kurulmuş, bağımsız

\footnotetext{
${ }_{61}$ S ve Marper/Birleşik Krallık, Başvuru No. 30562/04 ve 30566/04, 04.12.2008, para. 124.

62 S ve Marper/Birleşik Krallık, Başvuru No. 30562/04 ve 30566/04, 04.12.2008, para. 125.

63 PETERSON, s. 568.

64 Committee on the Rights of the Child, Frty-ninth session, Concluding observations: United Kingdom, 20 October 2008, (http://www2.ohchr.org/english/bodies/crc/docs/ AdvanceVersions/CRC.C.GBR.CO.4.pdf, erişim: 04.11.2019), para. 36.

65 HUGHES, s. 464.
} 
ve tarafsız bir mahkemede yargılanma hakk1, silahların eşitliği ilkesi, çekişmeli yargılama ilkesini kapsayan hakkaniyete uygun yargılanma hakk1, susma hakkı, gerekçeli karar hakkı, aleni yargılanma ve aleni hüküm hakları, makul sürede yargılanma hakları vardır ${ }^{66}$. İkinci fikrasında da suç isnadının karara bağlandığı davalarda sanıkların sahip olduğu haklar sıralanır. Buna göre, masumiyet karinesi, suçlama hakkında bilgilendirilme hakkı, savunma için gerekli zaman ve kolaylıklara sahip olma hakkı, kendini savunma ya da müdafii yardımından yararlanma hakkı, tanık dinletme ve tanığı sorgulama hakk1, ücretsiz tercümandan yararlanma hakları bulunur ${ }^{67}$.

Avrupa İnsan Hakları Mahkemesi, ceza ve özel yargılamalar esnasında çocukların özel yaşamlarını ilişkin çıkarları 8. madde kapsamında değil; adil yargılanma hakkını düzenleyen 6. madde kapsamında ele alır. Sözleşme'nin 6. maddesinin birinci fıkrası gereğince, yargılamalar, kural olarak aleni bir şekilde yapılmalıdır. Ancak, küçüklerin menfaatlerinin olduğu durumlarda, basın ve kamuya kapalı yargılamalar yapılmasına da imkân tanır ${ }^{68}$. Burada dikkat edilmesi gereken, madde 6 kapsamında çocukların yargılamalar esnasında özel hayata sayg1 hakkı öncelikli menfaat değildir; yalnızca açık yargılama yapılması şeklindeki genel kuralın istisnasıdır. Söz konusu istisna, çocukların hassasiyetinin farkına varılarak kabul edilmiştir ancak unutulmamalıdır ki, yargılamanın kapalı yapılıp yapılmayacağına ilişkin karar verilirken çocuğun çıkarları ile kamunun çıkarları arasında ortaya çıkacak menfaat çatışmasına ve bunlar arasında bir denge kurulmasına bakılacaktır ${ }^{69}$.

Söz konusu durumun somutlaştığı davalar, Birleşik Krallık aleyhine Avrupa İnsan Hakları Mahkemesi önüne taşınmıştır. T/Birleşik Krallık ${ }^{70}$ ve V/Birleşik Krallık ${ }^{71}$ davalarında, her ikisi de on yaşında olan çocuklar, iki yaşındaki bir çocuğu döverek öldürmekten dolayı mahkûm edilmişlerdir. Bazı özel önlemler kullanılmasına rağmen, haklarında görülen duruşma halka açık yapılmıştır ve mahkûmiyetlerinden sonrada çocukların isimleri gazetelerde yayınlanmıştır ${ }^{72}$. Bu durumun ardından her iki çocuk, yargılamanın aleni şekilde

\footnotetext{
66 İNCEOĞLU, ss. 215-277.

67 İNCEOĞLU, ss. 261-268.

68 HARRIS/O'BOYLE/WARBRICK, s. 434-435.

69 HUGHES, s. 465.

70 T/Birleşik Krallık, Başvuru No. 24724/94, 16.12.1999.

71 V/Birleşik Krallık, Başvuru No. 24888/94, 16.12.1999.

72 V/Birleşik Krallık, Başvuru No. 24888/94, 16.12.1999, para. 16.
} 
yapılmasının ve mahkûmiyet sonrası adlarının yayınlanmasının AİHS'nin 3. ve 6. maddelerinin ihlal edildiğini iddia etmiştir. Söz konusu başvuruda, başvurucular madde 8 temelinde herhangi bir iddiada bulunmamıştır ve Mahkeme'de davada bu maddeyle ilgili herhangi bir yorumda bulunmamıştır. İlgili olayda Mahkeme, AİHS' in 6. maddesinin ihlal edildiğine karar vermiştir. AİHS'nin 6. maddesinin ihlal edildiğine karar verirken, AİHM şiddetle çocukların uluslararası hukuka göre mahremiyetine sağlanan özel koruma ve özellikle de çocukların mahremiyetinin korunmasına yönelik güçlü eğilimden etkilenmiştir ve Mahkeme'ye göre, ciddi bir suçla yargılanan bir çocuğa basının ve toplumun çok büyük ilgi gösterdiği durumlarda, duruşmaların çocuğun korkmasını ve çekinmesini mümkün olduğunca önleyecek şekilde yürütülmesi sağlanmalıdır ${ }^{73}$.

Ceza yargılamalarının yanı sıra özel hukuk yargılamaları sırasında çocukların özel yaşamlarına saygı hakkının gündeme geldiği davalar sözkonusu olmuştur. Örneğin velayet davalarında çocuğun özel yaşama saygı hakkının değerlendirilmiş olduğu gözlenir. İlgili davaların geneline bakıldığında, ebeveynlerin özel bir şekilde yapılan velayet işlemlerinin kendi adil yargılanma haklarını ihlal iddiaları oluşturur. Diğer bir deyişle, ebeveynlerin 6. maddede düzenlenen adil yargılanma haklarıyla çocuğun 8 . maddede korunan özel yaşama saygı hakkının çatıştığı görülür. Çatışan menfaatler arasında Mahkeme'nin çocuğun özel yaşama saygı menfaatine birincil koruma sağlamadığı gözlenir. Çünkü Mahkeme ilgili davalarda çocuğun 8. maddede korunan haklarını doğrudan ele almamıştır. B ve P/Birleşik Krallık ${ }^{74}$ davasında, boşanma aşamasında olan başvuranların çocuklarına ilişkin ikamet işlemlerinin görüldüğü davada, duruşmanın özel olarak yapılmasının ve kararın kamuya açıklanmasının reddedilmesinin başvurucuların adil yargılanma hakkını ihlal edip etmediği hususu değerlendirilmiştir. İngiliz Hukuku'na göre, çocuğun özel yaşamının korunması amacıyla ikametgâh işlemlerine ilişkin duruşmaların özel olarak yapılması gerektiği kuralını Avrupa İnsan Hakları Mahkemesi 6. maddenin ihlali olarak değerlendirmemiştir. Mahkemeye göre, bu tür işlemler, basından ve toplumsal dışlanmadan çocuğu korumak için haklı gösterilebilecek davaların başlıca örnekleridir ${ }^{75}$. Mahkeme ilgili kararda her ne kadar çocuğun ihtiyaçlarına yönelik açıklamalarda bulunsa

73 T/Birleşik Krallık, Başvuru No. 24724/94, 16.12.1999, para. 85; V/Birleşik Krallık, Başvuru No. 24888/94, 16.12.1999, para. 87.

74 B ve P/Birleşik Krallık, Başvuru No. 36337/97, 35974/97, 2002.

75 B ve P/Birleşik Krallık, Başvuru No. 36337/97, 35974/97, 2002, para. 38. 
da, çocuğun AİHS'nin 8. maddesi uyarınca sahip olabileceği hakları dikkate almamıştır. Diğer bir deyişle, bu başvuruda da madde 8 açısından bir inceleme yapılmamıştır. Bu durumda çocuğun özel yaşama saygı hakkının göz ardı edilmesi tehlikesini bünyesinde taşır.

\section{Sonuç}

Avrupa İnsan Hakları Sözleşmesi'nin 8. maddesinde düzenlenen özel yaşama saygı hakkı çocuklar bakımından oldukça önemli olan bir haktır. Zira belirli yaşın altındaki küçüklerin irade yetileri bu hususta henüz gelişmemiştir. Dolayısıyla çocuğun özel alanı ve kişisel verileri üzerindeki hâkimiyeti yetişkinler gibi kendi kontrolü altında değildir. İlgili konularda kontrolöncelikle ailelere verilmiştir. Bu hususta Çocuk Hakları Sözleşmesi'nin 18. maddesi de hukuksal dayanak teşkil eder. İlgili madde açıkça çocuğun yetiştirilmesi ve geliştirilmesine ilişkin sorumluluğun öncelikle anne ve babada olduğunu belirtir. Devam eden maddede, çocuğun ebeveyninden bedensel veya zihinsel saldırı, şiddet, ihmal ya da ihmalkâr muamele, istismar ve kötü muameleye karşı korunması için devletlerin yasal, idari, toplumsal, eğitim gibi konularda önlemler almaları gereğini düzenler. Avrupa İnsan Hakları Mahkemesi de çocuğun özel yaşamına saygı hakkı kapsamında Çocuk Hakları Sözleşmesi'nin belirlediği bu kriterlere paralel ilerlemiştir. Örneğin, çocuğun üçüncü kişiler tarafından fotoğraflarının çekilmesinde ailesinin rızasının aranması gereğini belirtmiştir. Ebeveynler tarafından bu rıza gösterilmemişse çocuğun görüntüsünün korunması hakkından yola çıkarak özel yaşam hakkının ihlal edileceğini hüküm altına almıştır. Çocuğun özel yaşamına yönelik ebeveynler tarafindan bir müdahale söz konusu olduğunda ise devletlerin ebeveynlerin kötü niyetli eylemlerine karş1 pozitif yükümlülüklerinin de bulunduğunu belirtmiştir. Nitekim çocuk, kendi ailesinin yanında ve yaşamını sürdürdüğü evinde güvende hissetmek ister. Her daim ailesi tarafından fotoğraflanmak ya da kayıt altına alınmak her ne kadar masumane dursa da, onlar açısından oldukça zor bir durumdur. Bu gibi durumlarda aileler eliyle çocuklarının özel yaşamına saygı hakkı kapsamında kişilik haklarına müdahale gerçekleştiği söylenebilir. Devletlerin çocukların rızası olmadan aileleri tarafından evin içinde dahi olsa fotoğraflanması ya da videoya çekilmesi halinde, çocukların başvurabileceği yargısal yolları iç hukuklarında düzenlemeleri gerekir. Aksi halde çocuğun özel yaşamına saygı hakkı ihlal edilir.

$\mathrm{Bu}$ gibi hukuki ihtilafların yanı sıra devlet eliyle çocuğun kişisel verilerinin hukuka aykırı bir şekilde saklanmaya devam etmesi, ceza ve özel yargılamalar esnasında çocuğun kimlik bilgilerinin ya da fotoğraflarının 
kamuyla paylaşılması madde 8'i ihlal eder. Burada devletlerin çocukların gelişimi ve topluma dâhil olabilmesi için olası yıkıcı ve zararlı etkileri ortadan kaldırmayı amaç edinmeleri gerekir.

\section{KAYNAKÇA}

\section{Kitap ve Makaleler}

ALSTON, Philip/TOBIN, John, Laying the Foundations for Children's Rights: An Independent Study of Some Key Legal and Institutional Aspects of the Impact of the Convention on the Rights of the Child, (https://www.unicef-irc.org/publications/pdf/ii_layingthefoundations. pdf, erişim:04.11.2019).

BESSANT, Claire, "Sharenting: Balancing The Conflicting Rights Of Parents And Children", Communications Law, Vol. 23, Issue 1, 2018, ss. 7-24.

CASS, Bettina, "The Limits of the Public/Private Dictonomy: A Comment of Coady and Coady", ed. P. Alston, S. Palmer, J. Seymour, Children, Rights and the Law, Clarendon Press, Oxford, 1992, ss. 7-140.

Children's Commissioner, 'Life in Likes: A report into social media use among 8-12 year olds', January 2018, (www.childrenscommissioner. gov.uk, erişim: 04.11.2019).

Committee on the Rights of the Child, Frty-ninth session, Concluding observations: United Kingdom, 20 October 2008, (http://www2.ohchr. org/english/bodies/crc/docs/AdvanceVersions/CRC.C.GBR.CO.4.pdf, erişim: 04.11.2019).

DOĞRU, Osman/NALBANT, Atilla, İnsan Hakları Avrupa MahkemesiAçıklama ve Önemli Kararlar, 2. Baskı, Legal Yayıncılık, 2013, İstanbul.

ERIŞSiR, Rabia Merve/ERIŞíR, Deniz, "Yeni Medya ve Çocuk: Instagram Özelinde "Sharenting" (Paylaşananababalık) Örneği", Yeni Medya Dergisi, Say1 4-5, Bahar - Güz, 2018, ss. 50-64.

GLIGORIJEVIC, Jelena, “Children's Privacy: The Role of Parental Control and Consent, Human Rights Law Review, 19, 2019, ss. 201-229.

GÖZÜBÜYÜK, Şeref, GÖLCÜKLÜ, Feyyaz, Avrupa İnsan Hakları Sözleşmesi ve Uygulaması, 9. Baskı, Turhan Kitabevi, Ankara, 2011.

GRABENWARTER, Christoph, European Convention on Human Rights, 
Verlag C. H. Beck o HG, 2014.

GÜMÜŞ, Ali Tarık, Devletin Pozitif Yükümlülükleri Ekseninde Özel Hayata Saygı Hakkı, Adalet Yayınevi, 2016, Ankara, s. 147.

HARRIS/O'BOYLE/WARBRICK, Law of the European Convention on Human Rights, Oxford University Press, Third Edition, 2014.

HEPPLE, Bob, "Forensic Databases: Implications of the Cases of $\mathrm{S}$ and Marper", Medicine, Science and the Law, Vol. 49, No.2, 2009, ss. 77-87.

HERINGA, Aalt Willem/ZWAAK, Leo, "Right to Respect for Privacy", Theory And Practice Of The European Convention On Human Rights, ed. Pieter Van Dijk, Fried Van Hoof, Arjen Van Rijn, Leo Zwaak, Fourth Edition, Intersentia, Antwerpen, Oxford, 2006.

HUGHES, Kirsty, "The Child's Right to Privacy and Article 8 European Convention on Human Rights", ed. Michael Freeman, Law and Childhood Studies, Oxford University Press, 2012, ss. 456-486.

HUGHES, Kirsty, "Photographs in Public Places and Privacy", Journal of Media Law, 1:2, ss. 159-171.

JACOBS/WHITE/OVEY, The European Convention on Human Rights, 7. Bask1, Oxford University Press, 2017.

KINDT, Els J., Privacy and Data Protection Issues of Biometric Applications: A Comparative Legal Analysis, Springer eBook, 2013.

MOWBRAY, Alastair ,Cases, Materials and Commentary on the European

Convention On Human Rights, Oxford Universtiy Press, Third Edition, 2014.

ÖNCÜ, Gülay Arslan, Avrupa İnsan Hakları Sözleşmesinde Özel Yaşamın Korunması Hakkı, Beta Yayıncılık, 2011, İstanbul.

ÖNCÜ, Gülay Arslan, “Özel Yaşama ve Aile Yaşamına Saygı Hakkı”, İnsan Hakları Avrupa Sözleşmesi ve Anayasa, ed. Sibel İnceoğlu, 3. Baskı, Beta Yayınc1lik, İstanbul.

ÖZDEK, Yasemin, Avrupa İnsan Hakları Hukuku ve Türkiye, TODAİE Yayın1, 2004.

PETERSON, Anna, "S. v. United Kingdom: The European Court of Human Rights Overturns the United Kingdom's Procedure for the Indefinite 
Retention of Unconvicted Person's Personal Data", Tulane Journal of International and Comparative Law, Vol. 18, 2009, ss. 557-572.

Resolution 428 (1970) Containing a declaration on mass communication media and human rights,(http:/assembly.coe.int/nw/xml/XRef/XrefXML2HTML en.asp?fileid=15842\&lang=en., erişim: 05.11.2019).

SALİHPAŞAOĞLU, Yaşar, "Özel Hayatın Kapsamı: Avrupa İnsan Hakları Mahkemesi İçtihatları Işı̆̆ında Bir Değerlendirme”, Gazi Üniversitesi Hukuk Fakültesi Dergisi, C. XVII, S. 3, 2013, ss. 227- 266.

SCHABAS, William A., The European Convention On Human Rights A Commentary, Oxford University Press, 2015.

STEINBERG, Stacey B., "Sharenting: Children's Privacy In The Age Of Social Media”, Emory Law Journal, Vol. 66, 2017, ss. 839-884.

XENOS, Dimitris, The Positive Obligations of the State under the European Convention of Human Rights, Routledge Published, New York, 2012.

WARREN, Samuel D./BRANDEIS, Louis D., "The Right to Privacy", Harvard Law Review, Volume. IV, No. 5, December 15, 1980.

\section{Kararlar}

Amann/İsviçre (GC), Başvuru No. 27798/95, 16.02.2000.

Antovic and Mirkovic/Karadağ, Başvuru No. 70838/13, 28.11.2017.

B ve P/Birleşik Krallık, Başvuru No. 36337/97, 35974/97.

Barbulescu /Romanya, (BD) Başvuru No. 61496/08, 05.09.2017.

K.U./Finlandiya, Başvuru No. 2872/02, 02.03.2009.

Kurier Zeitungsverlag und Druckerei GmbH/Avusturya (No.2), Başvuru No. 1593/06, 19.06.2012

Markckx/Belçika, Başvuru No. 6833/74, 13.06.1979.

Mikulić/Hırvatistan, Başvuru No. 53176/99, 04.09.2002.

Niemietz/Almanya, Başvuru No. 13710/88, 16.12.1992.

Peck/Birleşik Krallık, Başvuru No. 44647/98, 28.04.2003.

Pretty/Birleşik Krallık, Başvuru No. 2346/02, 29.07.2002. 
Reklos ve Davourlis/ Yunanistan, Başvuru No. 1234/05, 15.04.2009.

S. ve Marper/Birleşik Krallık, Başvuru No.30562/04, 30566/04, 04.12.2008.

Satakunnan Markkinapörssi Oy and Satamedia Oy/Finlandiya (BD), Başvuru No.931/13, 27/06/2017.

Söderman/İsveç, Başvuru No. 5786/2008, 12.11.2013.

T/Birleşik Krallık, Başvuru No. 24724/94, 16.12.1999.

V/Birleşik Krallık, Başvuru No. 24888/94, 16.12.1999

Von Hannover/Almanya, Başvuru No. 59320/00, 03.06.2004.

X/İzlanda, Başvuru No. 6825/74, 18.05.1976. 
